\title{
Cytoprotective effect of reduced glutathione in arsenical-induced endothelial cell injury
}

\author{
Wen-Chang Chang, Shu-Huei Chen, Hau-Lin Wua ${ }^{a}$, Guey-Yueh Shi ${ }^{a}$, \\ Sei-itsu Murota ${ }^{\mathrm{b}}$ and Ikuo Morita*
}

Departments of Pharmacology and "Biochemistry, College of Medicine, National Cheng Kung University, Tainan, Taiwan (Republic of China) and ${ }^{h}$ Section of Physiological Chemistry, Faculty of Dentistry, Tokyo Medical and Dental University, Tokyo (Japan)

(Received January 28th, 1991; accepted July 22nd, 1991)

\section{Summary}

The effect of four arsenic compounds on cultured endothelial cells isolated from bovine carotid arteries was studied. Only trivalent arsenicals (arsenic trioxide and sodium $m$-arsenite), but not pentavalent arsenicals (arsenic acid and $p$-arsenilic acid), induced significant cell injury. Since the intracellular reduced glutathione (GSH) plays an important role in detoxication in mammalian cells, its effect on arsenicalinduced cell injury was then studied. Pretreatment of cells with $500 \mu \mathrm{M}$ GSH not only resulted in severalfold increase in the intracellular level of GSH but also effectively protected them against the injury caused by arsenic trioxide. After a pretreatment of cells with GSH for $3 \mathrm{~h}$, the intracellular GSH reached a plateau. A longer pretreatment for $24 \mathrm{~h}$ still kept GSH at a very significant high level. The cell injury induced by arsenic trioxide was protected by GSH, and then cellular biosynthesis of $\mathrm{PGI}_{2}$ in culture was also increased. The cytoprotective effect and the stimulatory effect on $\mathrm{PGI}_{2}$ production, where both were dose-dependent on GSH, were in a strict reverse relationship. Aspirin treatment inhibited the $\mathrm{PGI}_{2}$ biosynthesis induced by GSH in the arsenic trioxide-induced cell injury, and significantly reduced the cytoprotective effect induced by GSH. These results suggest that the marked stimulation of endogenous $\mathrm{PGI}_{2}$ biosynthesis by GSH is the mechanism of the latter's cytoprotective effect on arsenic trioxideinduced endothelial cell injury.

Key words: Arsenic; Endothelial cell injury; Reduced glutathione (GSH); Prostacyclin

\section{Introduction}

Arsenic is a rare environmental substance in terms of its carcinogenic response in humans and animal models. Exposure to inorganic arsenic compounds in drugs, drinking waters, and occupational environments is associated with increased risks of developing cancers of the skin, the lung and the liver (for review, see Ref. No. 1).

*Dr. Ikuo Morita was a visiting professor on leave from Section of Physiological Chemistry, Faculty of Dentistry, Tokyo Medical and Dental University, Tokyo, Japan.

Correspondence to: Dr. Wen-Chang Chang, Department of Pharmacology, College of Medicine, National Cheng Kung University, Tainan, Taiwan 70101, R.O.C.

0300-483X/91/\$03.50

(C) 1991 Elsevier Scientific Publishers Ireland Ltd.

Printed and Published in Ireland 
Blackfoot disease is an endemic peripheral vascular disorder among the inhabitants in a limited area on the southwest coast of Taiwan. It is limited to the people using deep-well drinking water which shows a variable, high concentration of arsenic. Chen and $\mathrm{Wu}[2]$ reported that the artesian well water of endemic areas of Blackfoot disease contains high concentration of arsenic $(0.1-0.35 \mathrm{ppm})$. The symptoms of Blackfoot disease are similar to those of Burger's disease and thromboangiitis obliterans [3]. It is characterized pathologically by injury of the peripheral vascular wall and by intravascular clot formation [4].

In the present study, an attempt was made to investigate effects of arsenicals on endothelial cells and of reduced glutathione (GSH) on the arsenical-induced cell injury. We found that trivalent arsenicals induced significant cell injury in cultured endothelial cells, and the injury was significantly reduced by GSH.

\section{Materials and methods}

\section{Chemicals}

$\left[{ }^{51} \mathrm{Cr}\right]$ Sodium chromate $(386 \mathrm{mCi} / \mathrm{mg})$ was purchased from NEN, Du Pont, Boston, U.S.A. 6-Keto-prostaglandin $F_{1 \alpha}\left[{ }^{125} \mathrm{I}\right]$ assay system was purchased from Amersham International plc, Bucks, U.K. Arsenic trioxide, sodium $m$-arsenite, arsenic acid, $p$-arsenilic acid, 5',5-dithiobis-2-nitrobenzoate (DTNB), bovine serum albumin (BSA), $\beta$-nicotinamide adenine dinucleotide phosphate-reduced form (NADPH), glutathione reductase and oxidized glutathione were from Sigma Chemical Co., St. Louis, U.S.A. GSH was obtained from Boehringer Mannheim GmbH, Mannheim, F.G.R. 2-Vinylpyridine was obtained from Aldrich Chemical Co., Milwaukee, USA. Aspirin was from Wako Pure Industries, Osaka, Japan. Dulbecco's modified Eagle medium and fetal bovine serum were purchased from GIBCO, NY, U.S.A. All other reagents used were of the highest purity available.

\section{Cell culture}

Endothelial cells were isolated from bovine carotid arteries as previously reported [5] and maintained in Dulbecco's modified Eagle medium (DMEM) containing 10\% fetal bovine serum. Cells of passages 15-25 were used in the present series of experiments.

\section{Endothelial cell injury assay}

Endothelial cell injury was estimated by the release of ${ }^{51} \mathrm{Cr}$ as previously described [6]. Confluent monolayer cells in 24 multiwell dishes (Falcone Labware) were prelabeled with $2 \mu \mathrm{Ci}$ of $\left[{ }^{51} \mathrm{Cr}\right]$ sodium chromate for $18 \mathrm{~h}$ in the growth medium. Cells were then washed twice with DMEM and treated with the arsenic compounds in $0.5 \mathrm{ml}$ of DMEM for $22 \mathrm{~h}$, unless stated otherwise. An aliquot of the cultured DMEM was removed and the radioactivity due to ${ }^{51} \mathrm{Cr}$ released by the injured cells was measured by a LKB 1282 Compugamma scintillation spectrophotometer. Results were expressed as percentage of specific ${ }^{51} \mathrm{Cr}$-release, calculated as follows: $(A-B) /(C-B) \times 100 \%$, where $A$ represents ${ }^{51} \mathrm{Cr}$-release due to the test compound; $B$ represents the spontaneous ${ }^{51} \mathrm{Cr}$-release and $C$ represents the maximum release of ${ }^{51} \mathrm{Cr}$. Spontaneous and maximum releases were determined in cells incubated with vehicle solvent and $0.1 \%$ Triton X-100, respectively. 
$\mathrm{PGI}_{2}$ determination

$\mathrm{PGI}_{2}$ production by endothelial cells was determined by assaying 6-keto $\mathrm{PGF}_{1 \alpha}$, a hydrolyzed product of $\mathrm{PGI}_{2}$. Content of 6-keto $\mathrm{PGF}_{1 \alpha}$ in cultured DMEM was determined by a specific 6-keto $\mathrm{PGF}_{1 \alpha}{ }^{125}$ I-radioimmunoassay with Amerlex-M magnetic separation from Amersham.

\section{Determination of intracellular GSH}

Confluent cells in 10-cm diameter petri dish were washed with $\mathrm{Ca}^{2+}$ - and $\mathrm{Mg}^{2+}$-free phosphate buffer saline, and $1.5 \mathrm{ml}$ of $10 \mathrm{mM} \mathrm{HCl}$ were added. Cells were scraped and sonicated by a Model W-375 Sonicator (Heat Systems-Ultrasonics, Inc.). The sonicated cell homogenate was centrifuged at $105000 \times g$ for $1 \mathrm{~h}$ by a Beckman L8-80 M ultracentrifuge. GSH content in the resulting supernatant was then determined. Total glutathione, including both the reduced and oxidized forms, was assayed according to the method described by Brehe and Burch [7]. In brief, one volume of ultracentrifuged supernatant was mixed with 1 vol. of reagent 1 . The reaction was then started by the addition of 1 vol. of reagent 2 , and was allowed to take place at $30^{\circ} \mathrm{C}$ for $15 \mathrm{~min}$, and the absorbance at $405 \mathrm{~nm}$ run was measured by a MR710 Microplate Reader (Dynatech). GSH at a range from 0.1 to $1.0 \mu \mathrm{M}$ was used as standards. Reagent 1 was sodium phosphate buffer ( $\mathrm{pH}$ 7.2) (110 $\mathrm{mM} \mathrm{Na}_{2} \mathrm{HPO}_{4}$, $40 \mathrm{mM} \mathrm{NaH} \mathrm{PO}_{4}$ ); EDTA, $15 \mathrm{mM}$; BSA, 0.04\%; and DTNB, $0.3 \mathrm{mM}$. Reagent 2 was imidazole-HCl buffer ( $\mathrm{pH}$ 7.2) ( $35 \mathrm{mM}$ imidazole, $15 \mathrm{mM}$ imidazole $\mathrm{HCl}$ ); EDTA, $1 \mathrm{mM}$; BSA, 0.02\%; NADPH, $0.6 \mathrm{mM}$; and glutathione reductase, $6 \mu \mathrm{g} / \mathrm{ml}(1.2$ $\mathrm{IU} / \mathrm{ml})$.

In order to measure oxidized glutathione, the GSH present in ultracentrifuged supernatant was readily derivatized by adding $2 \mu \mathrm{l}$ of neat 2-vinylpyridine $/ 100 \mu \mathrm{l}$ solution [8]. GSH was fully derivatized by $1 \mathrm{~h}$ reaction at $25^{\circ} \mathrm{C}$. The oxidized glutathione in the sample was then determined according to the methods as described above.

Content of GSH was then obtained by substracting the oxidized glutathione from the total glutathione.

\section{Protein determinations}

Protein content in the sonicated cell homogenate was determined by the method of Lowry et al. [9] with bovine serum albumin (fraction $\mathrm{V}$ ) as a standard.

\section{Results}

\section{Effect of arsenic compounds on endothelial cell}

The effect of four kinds of arsenic compounds; arsenic trioxide, sodium-marsenite, arsenic acid and $p$-arsenilic acid, on bovine endothelial cells was determined. Confluent endothelial cells were treated with one of these arsenic compounds for $22 \mathrm{~h}$. Figure 1 shows the results of such treatments. While arsenic acid and $p$-arsenilic acid did not show any significant effect, both $50 \mu \mathrm{M}$ arsenic trioxide and sodium $m$ arsenite induced significant injury of endothelial cells. With the two latter compounds, the degree of injury was dose-dependent. Therefore, arsenic trioxide was used in the following experiments. 


\section{Effect of exogenous GSH on intracellular GSH formation}

In order to investigate the effect of GSH on arsenical-induced cell injury, the intracellular GSH after the treatment of cells with GSH was determined. The basal level of intracellular GSH was $6.67 \mathrm{nmol} / \mathrm{mg}$ protein. A simple switch medium change with DMEM without serum and incubation up to $24 \mathrm{~h}$ did not lead to a significant change of this level. When the cells were treated with $500 \mu \mathrm{M} \mathrm{GSH}$, the intracellular GSH was markedly increased (Fig. 2). It reached a plateau of 43.66 $\mathrm{nmol} / \mathrm{mg}$ protein $3 \mathrm{~h}$ after the treatment. A long treatment, $24 \mathrm{~h}$ for example, still maintained the intracellular GSH at a significantly high level of $33.20 \mathrm{nmol} / \mathrm{mg}$ protein.

\section{Protection of arsenic trioxide-induced cell injury by GSH}

When the cells were treated with arsenic trioxide for $22 \mathrm{~h}$ in the presence of GSH, the cell injury induced by incubation with the former alone was inhibited (Fig. 3). The effect of GSH was maximum at the concentration of between 200 and $500 \mu \mathrm{M}$, and the inhibition was GSH dose-dependent. The inhibition was also dependent on the timing of GSH treatment as shown in Fig. 4. Pretreatment of the cells with GSH for $3 \mathrm{~h}$ resulted in $45 \%$ protection against cell injury induced by arsenic trioxide, and the presence of GSH in first $6 \mathrm{~h}$ of incubation with arsenic trioxide led to $75 \%$ cytoprotection. However, only $18 \%$ inhibition of cell injury was observed if GSH

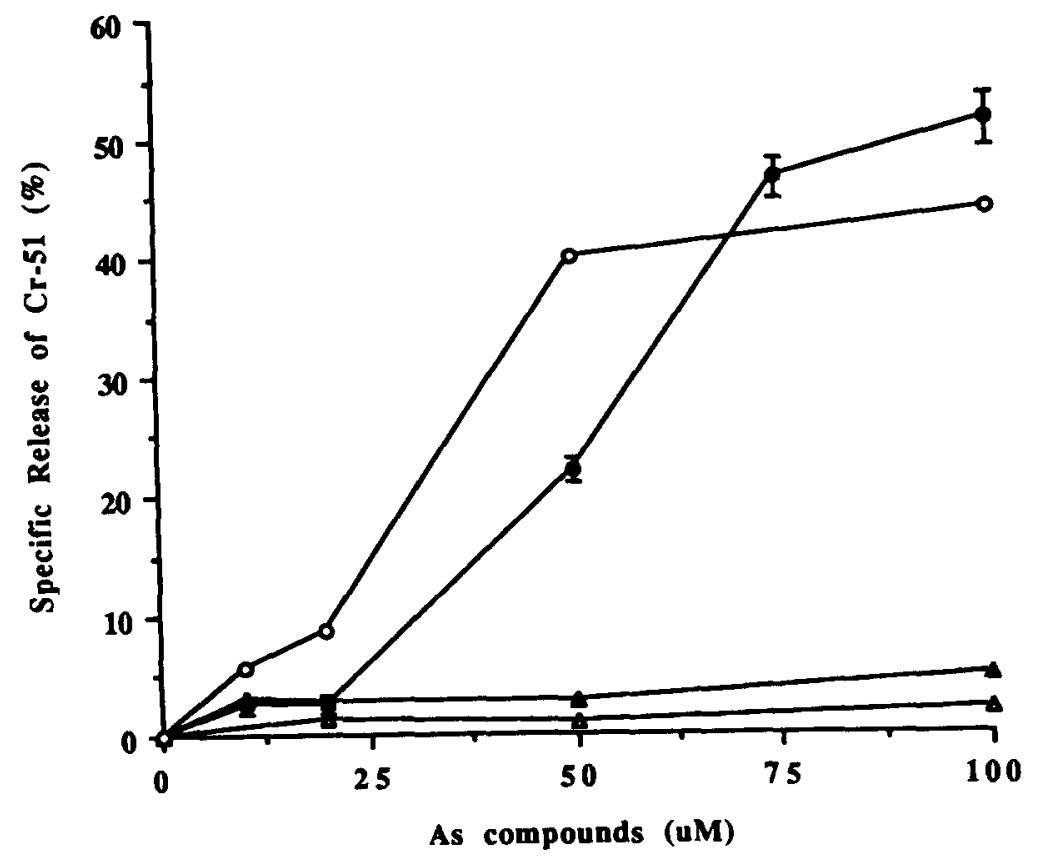

Fig. 1. Effect of arsenic compounds on endothelial cells. Confluent monolayer cells in 24 multiwell dishes were prelabeled with ${ }^{51} \mathrm{Cr}$ and then treated with arsenic trioxide $(-)$, sodium $m$-arsenite $(O)$, arsenic acid $(\boldsymbol{\Delta})$ and $p$-arsenilic acid $(\Delta)$ for $22 \mathrm{~h}$. Each value was the mean of triplicate assays. 


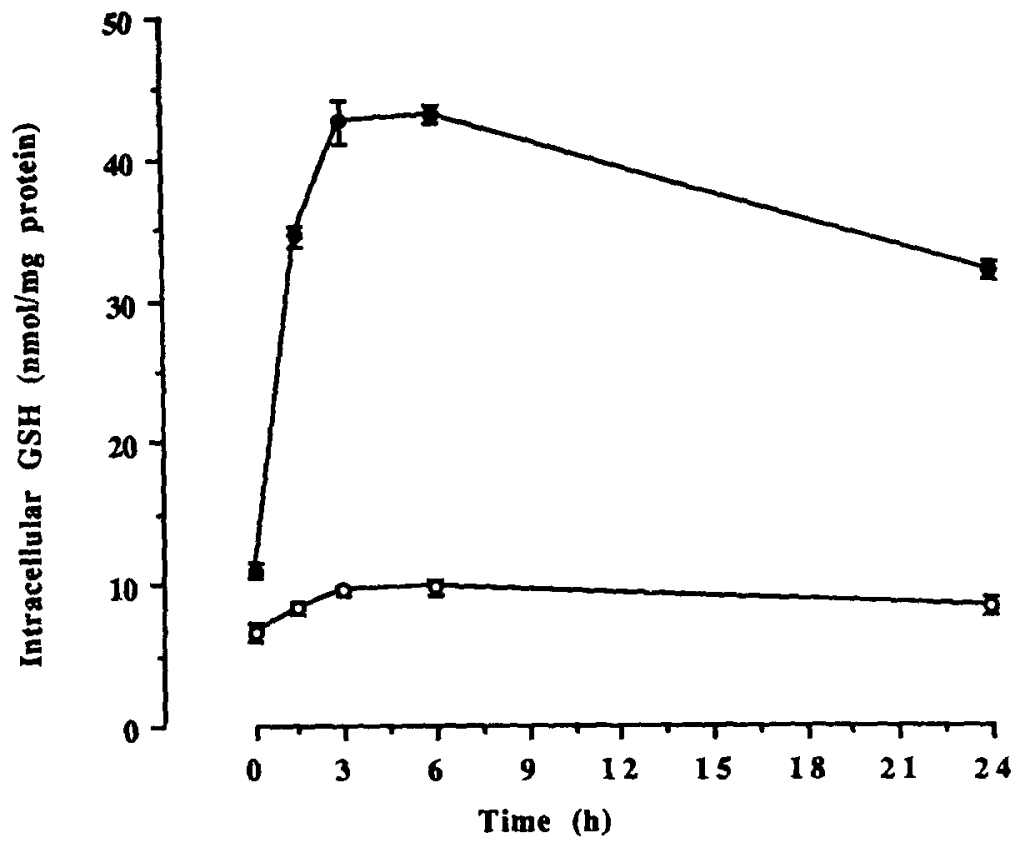

Fig. 2. Effect of exogenous GSH on intracellular GSH content. Confluent monolayer cells in $100 \times$ $20-\mathrm{mm}$ petri dishes were incubated in the presence $(0)$ or absence $(O)$ of $500 \mu \mathrm{M} \mathrm{GSH}$. Intracellular GSH was then assayed as described in Methods. Each value represents mean \pm S.E.M. from the triplicate assays.

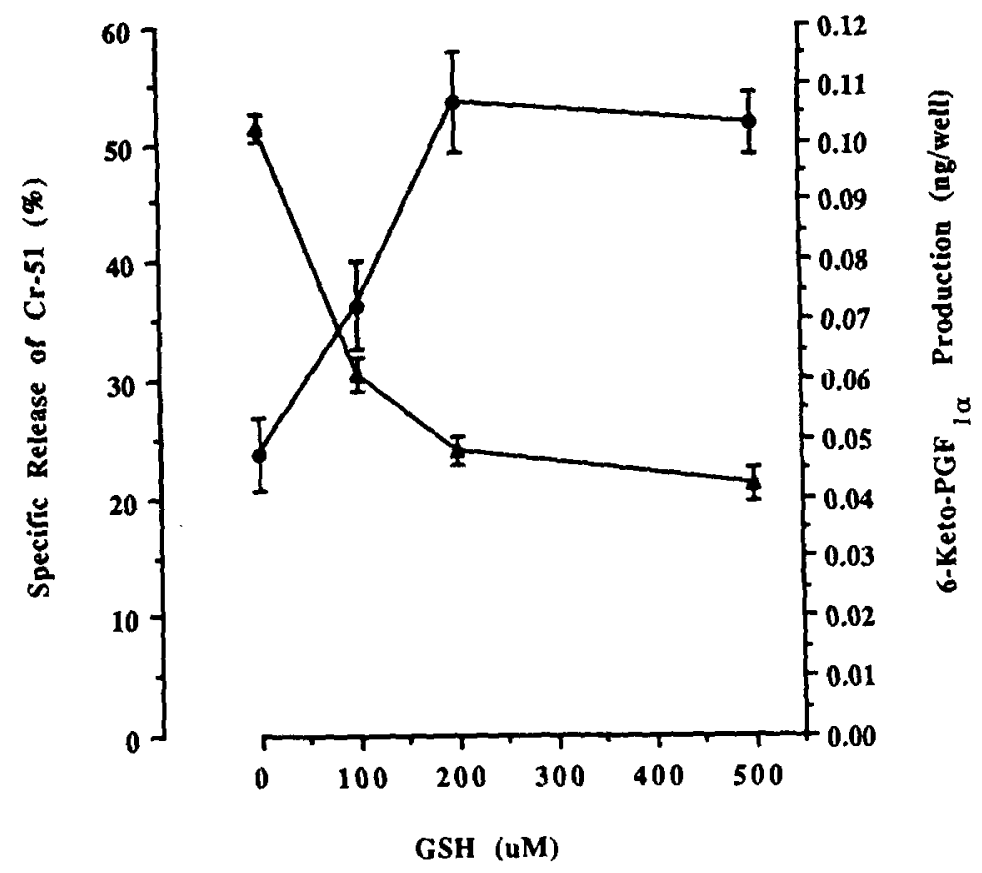

Fig. 3. Dose-response curves of GSH on $\mathrm{PGI}_{2}$ production and cell injury in arsenic trioxide-treated endothelial cells. Confluent monolayer cells in 24-multiwell plates prelabeled with or without ${ }^{51} \mathrm{Cr}$ were treated with $100 \mu \mathrm{M}$ arsenic trioxide in the absence or presence of different concentrations of GSH as indicated. After $1 \mathrm{~h}$ treatment, media were collected for $\mathrm{PGI}_{2}$ production assays ( $)$ ). Cell injury induced by $100 \mu \mathrm{M}$ arsenic trioxide for $22 \mathrm{~h}$ was also determined ( $)$. Each value represents mean \pm S.E.M. from the triplicate assays. 


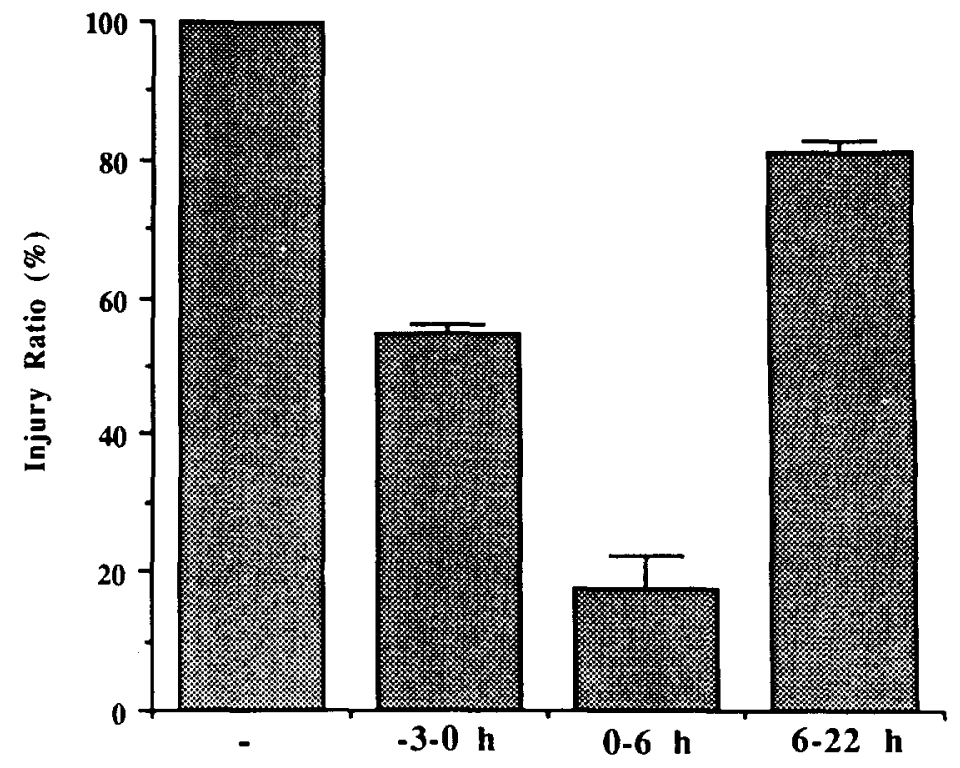

\section{Presence of glutathione}

Fig. 4. Cytoprotective effect of GSH as a function of treatment timing. Cell injury induced by $100 \mu \mathrm{M}$ arsenic trioxide treatment for $22 \mathrm{~h}$ was used for studying the time effect of GSH treatment, and regarded as $100 \%$ of injury for the comparison with GSH-treated groups. Three different treatments with the presence of $500 \mu \mathrm{M}$ GSH as indicated were performed. In the GSH-pretreated group, cells were pretreated with GSH for $3 \mathrm{~h}$. After washing with DMEM, treatment with arsenic trioxide was then performed. Each group was performed with triplicate assays.

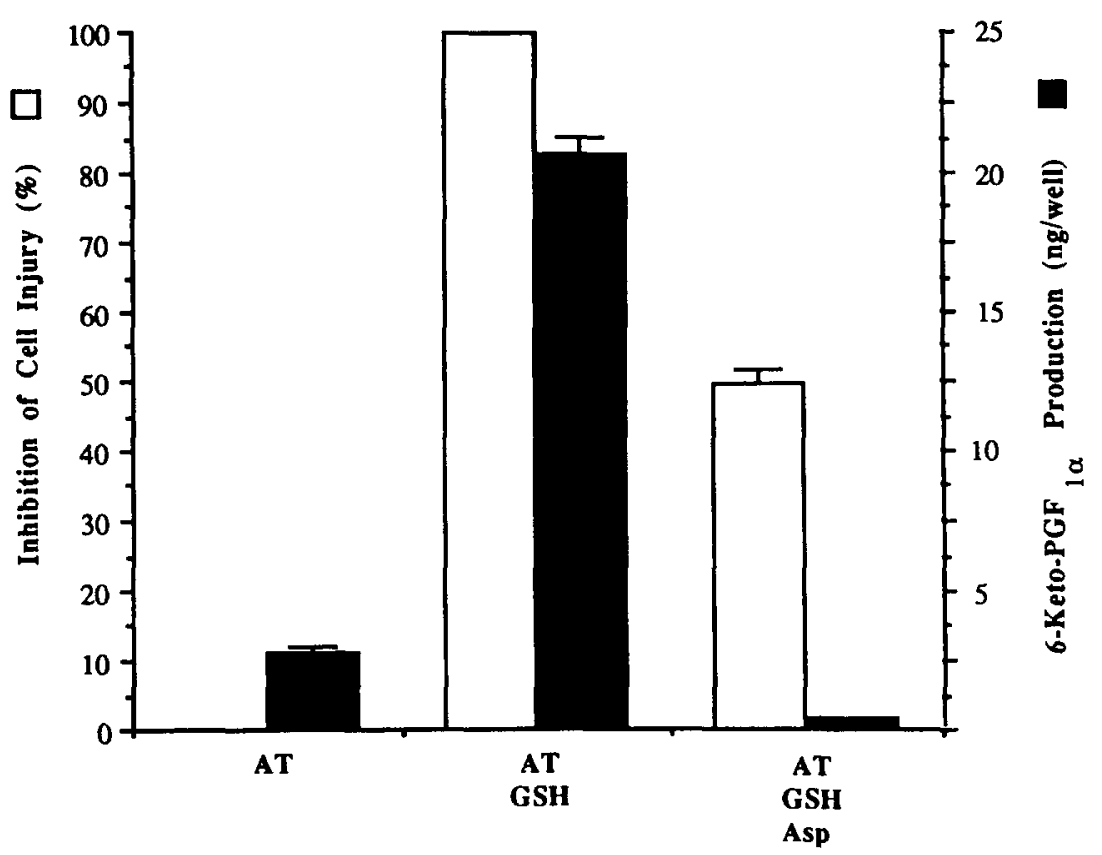

Fig. 5. Inhibition of cytoprotective effect of aspirin. Cell injury induced by $100 \mu \mathrm{M}$ arsenic trioxide (AT) treatment for $22 \mathrm{~h}$ was used in this experiment. During the $22-\mathrm{h}$ injury incubation, cells were treated with $500 \mu \mathrm{M}$ GSH in the absence or presence of $1 \mathrm{mM}$ aspirin (Asp). Media at $22 \mathrm{~h}$ treatment were collected for $\mathrm{PGI}_{2}$ production ( $\square$ ) and cell injury assays ( ${ }^{0}$ ) by GSH was regarded as $100 \%$ of inhibition. Each value represents mean \pm S.E.M. from the quadruplicate assays. 
treatment was started $6 \mathrm{~h}$ after arsenic trioxide treatment. These results indicate that obviously GSH had to be present before or along with arsenic trioxide in order to exert its protective effects. Our experiments, whose results are not presented here, clearly showed that oxidized glutathione did not have any cytoprotective effect against arsenical-induced endothelial cell injury.

\section{Effects of arsenic trioxide and $\mathrm{GSH}$ on $\mathrm{PGI}_{2}$ production}

The demonstration of the cytoprotective effect of GSH on endothelial cell injury induced by arsenic trioxide led us to study the effect of GSH on cellular $\mathrm{PGI}_{2}$ since $\mathrm{PGI}_{2}$ has been reported to have the cytoprotective effect in melittin-induced endothelial cell injury [10]. GSH itself did not have any demonstrable effect on the basal $\mathrm{PGI}_{2}$ biosynthesis in endothelial cells. However, it increased the $\mathrm{PGI}_{2}$ production, in a dose-dependent manner, by endothelial cells treated with arsenic trioxide (Fig. 3). The cytoprotective effect and the stimulatory effect on $\mathbf{P G I}_{2}$ production, where both were dose-dependent on GSH, were in a reverse relationship.

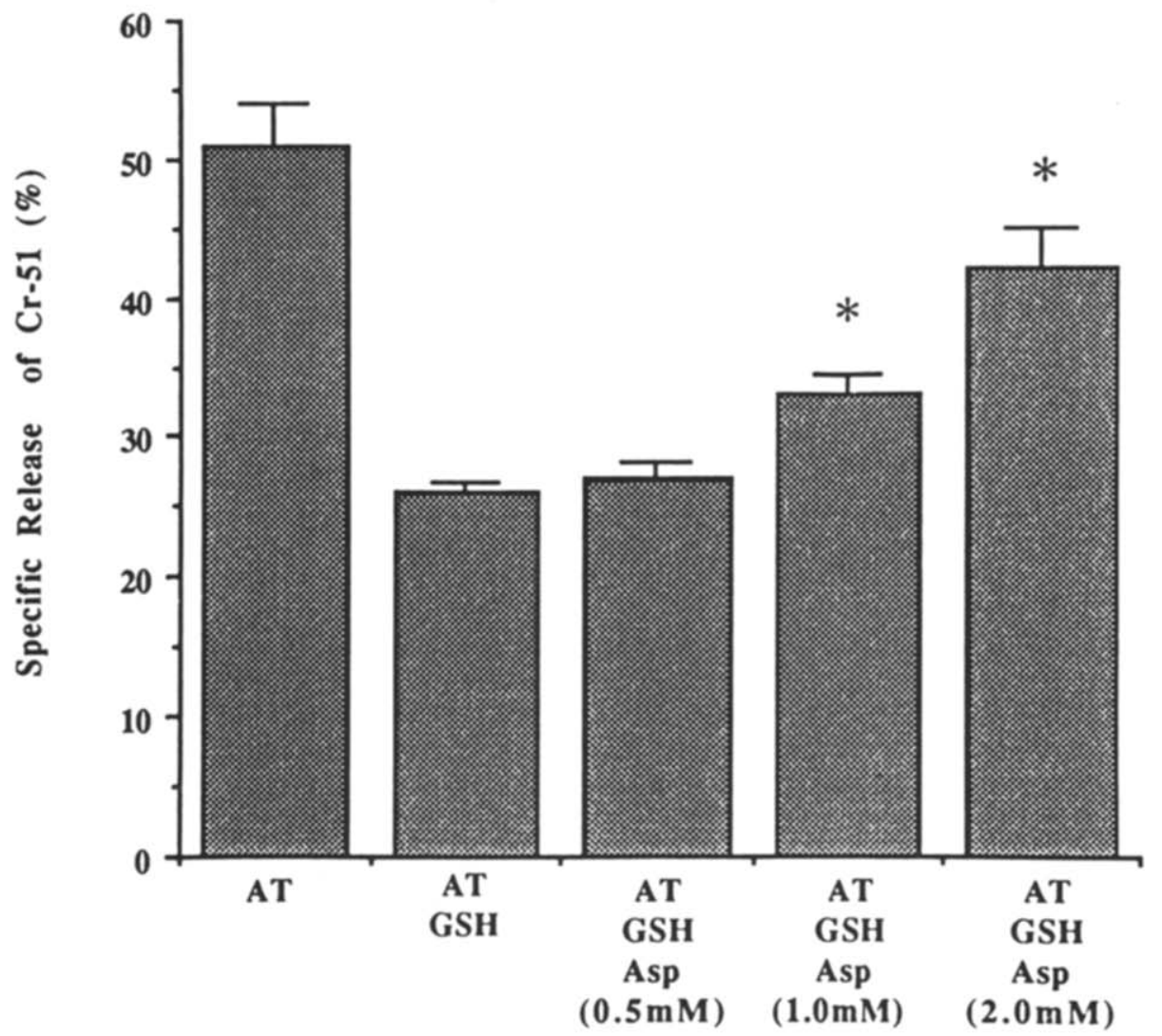

Fig. 6. Dose response of aspirin on the cytoprotective effect of GSH in arsenic trioxide-treated endothelial cells. Cells injury induced by $100 \mu \mathrm{M}$ arsenic trioxide (AT) treatment for $22 \mathrm{~h}$ was used in this experiment. During the 22-h injury incubation, cells were treated with $500 \mu \mathrm{M} \mathrm{GSH}$ and/or treated with different concentrations of aspirin (Asp). Each group was performed with quadruplicate assays. Data were analyzed statistically by Student's $t$-test. The aspirin-treated groups were compared with the group treated with arsenic trioxide and GSH. ${ }^{*} P<0.01$. 
The above presented data strongly suggest that the cytoprotective effect of GSH was due to the stimulation of $\mathrm{PGI}_{2}$ biosynthesis. Since aspirin specifically inactivates the fatty acid cyclooxygenase activity [11], change in the cytoprotective effect of GSH under aspirin treatment was studied. As shown in Fig. $5,1 \mathrm{mM}$ aspirin treatment inhibited $\mathrm{PGI}_{2}$ biosynthesis completely and also reduced the cytoprotective effect of GSH by $50 \%$. Moreover, the inhibition of the cytoprotective effect of GSH by aspirin was dose-dependent (Fig. 6). Aspirin alone did not show any significant cytotoxic effect. These results indicate that the stimulation of endogenous $\mathrm{PGI}_{2}$ biosynthesis by GSH was the underlying mechanism by which it exerted the cytoprotective effect on arsenic trioxide-induced cell injury.

\section{Discussion}

Arsenate is thought to be reduced in vivo to the trivalent arsenite, which is the active form in animal tissues [12,13]. Trivalent arsenicals are regarded as primarily sulfhydryl ( $\mathrm{SH})$ reagents, because they inhibit a number of thiol-dependent enzyme systems in various tissues, e.g. pyruvate oxidase, xanthine oxidase, cytochrome $b$, among others $[14,15]$. GSH, a tripeptide thiol present in virtually all cells, plays an important role in the protection of diverse tissues against reactive $\mathrm{O}_{2}$ species and free radicals [16]. In $\mathrm{H}_{2} \mathrm{O}_{2}$-induced cell injury of cultured porcine pulmonary artery endothelial cells, Suttorp et al. [17] reported that the injury is dramatically increased when the glutathione redox cycle is impaired, indicating that GSH directly protects against cell injury.

Among the arsenic compounds used in this study, arsenic trioxide and sodium $m$ arsenite were trivalent, while arsenic acid and $p$-arsenilic acid were pentavalent, and only trivalent arsenicals (arsenic trioxide and sodium $m$-arsenite) induced significant cell injury in cultured bovine carotid artery endothelial cells (Fig. 1). This corresponds to the observations made in in vivo studies described above. Since this injury could readily be reversed by reduced form of glutathione, but not by its oxidized form, the injury caused by arsenic trioxide may be due to the interruption of cellular thiol-dependent enzyme systems. Tsan et al. [18] reported that treatment of cultured bovine pulmonary artery endothelial cells with exogenous GSH markedly enhances the cellular GSH, due to the extracellular breakdown and subsequent intracellular resynthesis of GSH. In our experiments, we confirmed that the maximum level of intracellular GSH in cells treated with $200 \mu \mathrm{M}$ GSH increased 6-fold compared with the basal level in control cells. The maximum level was reached $3 \mathrm{~h}$ after the treatment with GSH and maintained at a significantly high level up to $24 \mathrm{~h}$. Pretreatment of the cells with GSH for $3 \mathrm{~h}$ produced $45 \%$ protection against cell injury induced by arsenic trioxide (Fig. 4), indicating that the increased intracellular GSH could remedy whatever biological responses were induced by arsenic trioxide in cells, although they have not been identified yet. However, the simultaneous treatment with GSH and arsenic trioxide in the first $6 \mathrm{~h}$ in cells gave the best cytoprotective effect (Fig. 4), suggesting that the direct interaction between GSH and arsenic trioxide is also possible. The mechanism remains to be clarified.

$\mathrm{PGI}_{2}$ is known to be a potent vasodilator [19], an inhibitor of platelet aggregation [20] and an inhibitor of smooth muscle cell proliferation [21]. The impaired 
$\mathrm{PGI}_{2}$ synthetic capacity in vascular wall has in fact been observed to occur in vascular disorder $[22,23]$. We therefore studied the $\mathbf{P G I}_{2}$ biosynthesis in cells during the treatment of arsenic trioxide and GSH. Presence of GSH in arsenic trioxidetreated cells induced a marked increase in the cellular $\mathrm{PGI}_{2}$ production (Fig. 3). In order to study the possible role of endogenous $\mathrm{PGI}_{2}$ in arsenic trioxide-induced cell injury, aspirin was used in this series of experiments since it is a well-known inhibitor of fatty acid cyclooxygenase [11]. Since aspirin significantly blocked the cytoprotective effect of GSH (Fig. 5), the cytoprotective effect of GSH in arsenic trioxideinduced cell injury may be due to the increase in cellular $\mathrm{PGI}_{2}$ production. These results taken together indicate that the endogenous $\mathrm{PGI}_{2}$ may partly contribute to the cytoprotective effect of GSH on endothelial cells injured by arsenic trioxide, though there is little information indicating that the endogenous $\mathrm{PGI}_{2}$ has cytoprotective effects in cultured endothelial cells so far. This may be due to the difficulty of directly studying the cytoprotection mechanism of endogenously produced $\mathrm{PGI}_{2}$ since it is very labile with a short half-life less than several minutes [20]. Experiments with its stable analogues might be useful. Further studies on the underlying mechanism of the cytoprotective effects of GSH on arsenical-induced endothelial cell injury are necessary.

\section{Acknowledgements}

We are greatly indebted to Ms. Y.F. Lu, and Mr. T.F. Tsai for their excellent technical assistance. Thanks are also due to Dr. K.Y. Huang for his critical review of this manuscript and to Ms. Y.J. Chang for her secretarial assistance. This research was supported in part by National Science Council of the Republic of China (NSC 78-0412-B006-46 and NSC 79-0412-B006-31).

\section{References}

1 A. Leonard and R.R. Lauwerys, Carcinogenicity, teratogenicity and mutagenicity of arsenic. Mutat. Res., 75 (1980) 49.

2 K.P. Chen and H.Y. Wu, Epidemiologic studies on Blackfoot disease, 2. A study of source of drinking water in relation to the disease. J. Formosan Med. Assoc., 61 (1962) 611 .

3 S. Yeh and S.W. How, A pathological study of the Blackfoot disease in Taiwan. Reports, Institute of Pathology, National Taiwan University, 14 (1963) 25.

4 W.P. Tseng, Outcome of patients with Blackfoot disease. J. Formosan Med. Assoc., 74 (1975) 37.

5 Y. Sasaguri, M. Morimatsu, T. Kinoshita, T. Nakashima. T. Inagaki and K. Yagi, Difference in susceptibility to injury by linoleic acid hydroperoxide between endothelial and smooth muscle cells of arteries. J. Appl. Biochem., 7 (1985) 70.

6 M. Abe, I. Morita and S. Murota, A new in vitro method using Fura-2 for the quantification of endothelial cell injury. Prostagl. Leukotr. Essentl. Fatty Acids, 34 (1988) 69.

7 J.E. Brehe and H.B. Burch, Enzymatic assay for glutathione. Anal. Biochem., 74 (1976) 189.

8 O.W. Griffith, Determination of glutathione and glutathione disulfide using glutathione reductase and 2-vinylpyridine. Anal. Biochem., 106 (1980) 207.

9 O.H. Lowry, N.J. Rosebrough, A.L. Farr and R.J. Randall, Protein measurement with the Folin phenol reagent. J. Biol. Chem., 193 (1951) 265.

10 A.R. Johnson. G. Revtyak and W.B. Campbell, Arachidonic acid metabolites and endothelial injury: Studies with cultures of human endothelial cells. Fed. Proc., 41 (1985) 19. 
11 J.R. Vane, Inhibition of prostaglandin synthesis as a mechanism of action for aspirin-like drugs. Nature New Biol., 231 (1971) 232.

12 J.M. Ginsburg, Renal mechanism for exeretion and transformation of arsenic in the dog. Am. J. Physiol., 208 (1965) 832.

13 J.M. Ginsburg and W.W. Lotspeich, Interrelations of arsenate and phosphate transport in the dog kidney. Am. J. Physiol., 205 (1964) 707.

14 G.L. Cottam and R.A. Srere, The sulphydryl groups of citrate cleavage enzyme. Arch. Biochem. Biophys., 130 (1969) 304.

15 I. Hassinen and $M$. Hallman, Comparison of the effects of disulfiram and dimercaptopropanol arsenite on mitochondrial structure and function. Biochem. Pharmacol., 16 (1967) 2155.

16 A. Meister and M.E. Anderson, Glutathione. Annu. Rev. Biochem., 52 (1983) 711

17 N. Suttorp, W. Toepfer and L. Roka, Antioxidant defense mechanisms of endothelial cells: glutathione redox cycle versus catalase. Am. J. Physiol., 251 (1986) C671.

18 M.F. Tsan, J.E. White and C.L. Rosano, Modulation of endothelial GSH concentrations: effect of exogenous GSH and GSH monoethyl ester. J. Appl. Physiol., 66 (1989) 1029.

19 J.M. Armstrong, N. Lattimer, S. Moncada and J.R. Vane. Comparison of the vasodepressor effects of prostacyclin and 6-oxo-prostaglandin $F_{1 \alpha}$ with those of prostaglandin $E_{2}$ in rats and rabbits. Br. J. Pharmacol., 62 (1978) 125.

20 S. Moncada, R. Gryglewski, S. Bunting and J.R. Vane, An enzyme isolated from arteries transforms prostaglandin endoperoxides to an unstable substance that inhibits platelet aggregation. Nature, 263 (1976) 633.

21 J.J. Huttner, E.T. Gwebu, R.V. Panaganamala, G.E. Milo, D.G. Cornwell, H.M. Sharma and J.C. Geer, Fatty acids and their derivatives: inhibitors of proliferation in aortic smooth muscle cells. Science, 197 (1977) 289.

22 H. Sinzinger, K. Silberbauer, M. Winter and P. Clopath, Effects of experimental atherosclerosis on prostacyclin $\left(\mathrm{PGI}_{2}\right)$ generation in arteries of miniature swine. Artery, 5 (1979) 448.

23 A. Dembinska-Kiec, W. Rucker and R.S. Schonhofer, Atherosclerosis decreased prostacyclin formation in rabbit lungs and kidneys. Prostaglandins, 17 (1979) 831. 